\title{
Normal spontaneous and stimulated GH levels despite decreased IGF-I concentrations in cystic fibrosis patients
}

\author{
E M Laursen, S Lanng ${ }^{1}$, M H Rasmussen ${ }^{2}$, C Koch $^{1}$, N E Skakkebæk and J Müller \\ Department of Growth and Reproduction GR and ${ }^{1}$ Departmemt of Pediatrics GGK, State University Hospital, Rigshospitalet, Copenhagen, \\ Denmark and ${ }^{2}$ Department of Endocrinology, Hvidovre University Hospital, Copenhagen, Denmark \\ (Correspondence should be addressed to E M Laursen, Department of Growth and Reproduction GR, Rigshospitalet, Blegdamsvej 9, \\ DK-2100 Copenhagen Ø, Denmark)
}

\begin{abstract}
Objective: The aim of the present study was to investigate whether patients with cystic fibrosis (CF) are $\mathrm{GH}$ resistant with increased GH release and decreased concentrations of IGF-I as a result of malabsorption, increased catabolism and impaired glucose tolerance.

Design: Twenty CF patients were included, ten with normal glucose tolerance (five male, five female, median age 25.5 years (range 20-31)) and ten with diabetes mellitus (five male, five female, median age 25.3 years (range 17-45). Twenty healthy individuals served as controls (ten male, ten female, median age 28.4 years (range 18-36)).

Methods: GH status was evaluated by $12 \mathrm{~h}$ spontaneous GH release during the night time, argininestimulated GH release and the basal concentrations of IGF-I and insulin-like growth factor-binding protein-3 (IGFBP-3). Twelve hour spontaneous GH profiles were estimated using a constant blood withdrawal technique with sampling every $30 \mathrm{~min}$ and the Pulsar method was used for the analysis of profiles.

Results: No significant differences were found in spontaneous and stimulated GH release in CF patients compared with healthy controls, whereas IGF-I and IGFBP-3 were significantly decreased in CF patients compared with healthy controls. The combination of reduced IGF-I and IGFBP-3 with normal GH release points to a relative GH resistance or a disturbance in the pituitary axis in patients with CF. The spontaneous GH release, the stimulated GH release and the basal concentrations of IGF-I and IGFBP-3 were not significantly different in diabetic CF patients compared with CF patients with normal glucose tolerance and the presence of diabetes mellitus was not consistent with increased GH resistance in $\mathrm{CF}$ patients.

Conclusion: CF patients with normal glucose tolerance and diabetic CF patients had normal GH release and decreased concentrations of IGF-I indicating a relative GH resistance.
\end{abstract}

European Journal of Endocrinology 140 315-321

\section{Introduction}

Patients with cystic fibrosis (CF) suffer from several different symptoms, among which pulmonary infections and malabsorption are the most prominent (1). Younger patients can usually be well controlled with intensive antibiotic treatment and pancreatic enzyme substitution (2). However, with increasing age CF patients often develop a catabolic condition with decline in body mass index (BMI), chronic pulmonary infection and impaired glucose metabolism (3). A delay in sexual maturation followed by a delay in the pubertal increment in several anabolic hormones such as sex hormones and growth hormone (GH) may also contribute to an increased catabolism (4-6).

We have previously shown diminished concentrations of insulin-like growth factor-I (IGF-I) in patients with CF (7). This was later confirmed by Taylor et al. (8), who found the most pronounced abnormalities in IGFI and insulin-like growth factor-binding protein-3 (IGFBP-3) in patients with CF during late puberty. The decreased concentrations of IGF-I in patients with $\mathrm{CF}$ might presumably cause an increase in $\mathrm{GH}$ secretion due to lack of negative feedback on somatotrophic cells in the anterior pituitary gland (9). Conversely, decreased IGF-I concentrations might be secondary to $\mathrm{GH}$ resistance $(10,11)$. GH resistance is characterized by a disturbance in the physiological relationship between GH secretion, IGF-I synthesis and the biological actions of $\mathrm{GH}$. The classical form of primary GH resistance due to a defect in the $\mathrm{GH}$ receptor is by far the most common; however, GH resistance may also be secondary (10). Malnutrition is known to cause GH resistance, which is normalized in response to nutritional 
supplementation (12). Catabolic states, as seen in severely ill patients may lead to GH resistance (13) and in poorly controlled patients with diabetes mellitus (DM) abnormally high GH secretion and relative IGF-I deficiency have been observed $(14,15)$.

The aim of this study was to investigate whether patients with $\mathrm{CF}$ are GH resistant. We measured the spontaneous as well as the stimulated GH release and compared the results with IGF-I and IGFBP-3, glucose tolerance and BMI in adult patients with $\mathrm{CF}$ and in healthy controls.

\section{Patients and methods}

\section{Patients}

Twenty adult patients with CF and chronic pulmonary infection with Pseudomonas aeruginosa were included, ten with normal glucose tolerance (NGT) (five male, five female, median age 25.5 years (range 20-31)), and ten with DM (five male, five female, median age 25.3 years (range 17-45)). Cut off values of $2 \mathrm{~h}$ post glucose load capillary plasma glucose concentration $\leqslant 8.8 \mathrm{mmol} / \mathrm{l}$ for NGT and $\geqslant 12.2 \mathrm{mmol} / \mathrm{l}$ for DM were used, according to WHO recommendations (16). The results were compared with an age- and sex-matched group of 20 healthy controls (10 male, 10 female, median age 28.4 years (range 18-36)). These controls had NGT as judged by fasting capillary plasma glucose $(\leqslant 7.8 \mathrm{mmol} / \mathrm{l})$ and glycated haemoglobin $(\leqslant 0.063 \mathrm{mmol} / \mathrm{l})$. The controls had significantly higher BMIs than did the CF patients (23.17 (19.5$26.2)$ vs 19.50 (15.4-25.1), $P<0.0001)$.

Ethics The study was carried out in accordance with the Helsinki II declaration and approved by the local ethics committee of Copenhagen, Denmark (approval no. 01-008/93 and 01-027/97). Written informed consent was obtained from each participant and from the parents of the participant below 18 years of age.

\section{Methods}

Spontaneous GH release was evaluated from a $12 \mathrm{~h}$ profile from approximately $19.00 \mathrm{~h}$ to $07.00 \mathrm{~h}$ with blood specimens being sampled every $30 \mathrm{~min}$ (24 samples). A constant withdrawal pump connected to a non-thrombogenic catheter was used according to the Cormed-Kowarski method (17). The stimulated GH release was evaluated by an arginine stimulation test (L-arginine monohydrochloride $0.5 \mathrm{~g} / \mathrm{kg}$ body weight infused i.v. over $30 \mathrm{~min}$ ) with blood samples $30 \mathrm{~min}$ before, immediately before and 10, 20, 30, 45, 60, 90, 120 and $150 \mathrm{~min}$ after the start of arginine infusion.

In diabetic $\mathrm{CF}$ patients, insulin therapy was withheld for the last $12 \mathrm{~h}$ before measuring spontaneous $\mathrm{GH}$ release and for the last $24 \mathrm{~h}$ before arginine stimulation.
GH was quantified using an immunofluorometric assay (trIFMA, Delfia, Wallac, Pharmacia Biosystems, Allerød, Denmark). In our laboratory the intra-assay coefficients of variation were $9.7,2.2$ and $1.2 \%$ at serum concentrations of $0.4,14.1$ and $59.8 \mathrm{mU} / \mathrm{l}$ respectively. Interassay coefficients of variation were $6.2,6.0$ and $2.3 \%$ at serum concentrations of $1.2,16.4$ and $58.2 \mathrm{mU} / \mathrm{l}$ respectively. The lower detection limit of the human $\mathrm{GH}$ kit was approximately $0.05 \mathrm{mU} / \mathrm{l}$. All samples from each subject were measured simultaneously in the same assay.

The Pulsar method, which is based on computerized algorithms (18), was used to characterize the pattern of secretory episodes and identify $\mathrm{GH}$ pulses in the $\mathrm{GH}$ profiles. The following values were extracted from the Pulsar analysis for the evaluation of the spontaneous $\mathrm{GH}$ profiles: the smoothed $12 \mathrm{~h}$ mean, the maximum value, the number of peaks, the mean peak amplitude, the mean peak area, and the area under the curve (AUC) estimated above the calculated baseline. The Pulsar program was set up so that the probability of detecting a peak in a series without peaks was below $5 \%(19)$.

IGF-I was measured by RIA on acid-ethanol extracted serum including a cryoprecipitation step using monoiodinated $\left[{ }^{125} \mathrm{I}_{-} \mathrm{Tyr}^{31}\right]$-des- $(1-3)-\mathrm{IGF}-\mathrm{I}$ as radioligand. Interassay and intra-assay coefficients of variation were 8.7 and $3.9 \%$ respectively at a bound/ free ratio of 0.4 (20). A specific RIA previously described by Blum et al. (21) was used to determine IGFBP-3.

\section{Statistics}

The statistical analyses were performed in a statistical package (SPSS/PC+). Non-parametric methods were used. The Mann-Whitney test was used to compare two different groups. The Kruskal-Wallis test was used for comparison of three groups.

Linear regression analysis was used to investigate the degree of correlation between variables.

\section{Results}

There were no significant differences in the spontaneous $\mathrm{GH}$ release (Table 1), the arginine-stimulated peak $\mathrm{GH}$ release (Table 2) or the basal concentrations of IGF-I and IGFBP-3 (Table 2) between patients with NGT and DM, and therefore data from the two groups were pooled for analysis.

None of the characteristics of the spontaneous GH release showed significant differences between $\mathrm{CF}$ patients and controls (Table 1 ). Figure 1 shows different examples of $\mathrm{GH}$ release profiles in individual $\mathrm{CF}$ patients and controls. Different types of secretory pattern were found equally in both groups (Fig. 1).

BMI correlated significantly to mean GH secretion $(r=-0.41, P<0.01)$ but not to any other parameter used to characterize the spontaneous GH release. 
Table 1 Characteristics of $12 \mathrm{~h} \mathrm{GH}$ release in diabetic CF patients (CF-DM), patients with normal glucose tolerance (CF-NGT) and healthy controls. Values are median (range).

\begin{tabular}{|c|c|c|c|c|}
\hline & $\begin{array}{l}\text { Controls } \\
(n=20)\end{array}$ & $\begin{array}{l}\text { CF-NGT } \\
(n=10)\end{array}$ & $\begin{array}{l}\text { CF-DM } \\
(n=10)\end{array}$ & $\begin{array}{l}\text { CF-NGT and CF-DM } \\
\qquad(n=20)\end{array}$ \\
\hline $12 \mathrm{~h}$ mean $\mathrm{GH}(\mathrm{mU} / \mathrm{l})$ & $2.66(0.5-9.3)$ & $\begin{array}{l}2.99(1.1-10.2) \\
\star P=0.36\end{array}$ & $4.53(1.45-14.3)$ & $\begin{array}{l}3.7(1.1-14.3) \\
{ }^{* *} P=0.39\end{array}$ \\
\hline AUC to baseline $(\mathrm{mU} / \mathrm{l} \times 12 \mathrm{~h})$ & $51.85(7.8-191.0)$ & $\begin{array}{l}42.74(14.1-185.2) \\
{ }^{*} P=0.26\end{array}$ & $68.67(28.0-106.7)$ & $\begin{array}{l}62.90(14.1-185.2) \\
{ }^{* \star} P=0.77\end{array}$ \\
\hline No. of GH peaks & $4(2-5)$ & $\begin{array}{l}4.5(3-6) \\
{ }^{\star} P=0.56\end{array}$ & $4.5(3-6)$ & 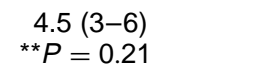 \\
\hline Maximum value of $\mathrm{GH}(\mathrm{mU} / \mathrm{l})$ & $13.70(2.0-70.6)$ & $\begin{array}{l}14.30(6.1-51.9) \\
{ }^{*} P=0.45\end{array}$ & $22.25(0.3-38.3)$ & 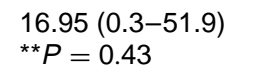 \\
\hline Peak amplitude of $\mathrm{GH}$ (mU/l) & $5.73(1.0-21.8)$ & $\begin{array}{l}5.35(2.4-31.3) \\
{ }^{*} P=0.45\end{array}$ & $8.54(2.9-11.0)$ & $\begin{array}{l}7.61(2.4-31.3) \\
{ }^{* *} P=0.65\end{array}$ \\
\hline Peak area of GH (mU/l) & $13.02(1.9-47.5)$ & $\begin{array}{l}11.20(2.7-61.2) \\
{ }^{\star} P=0.41\end{array}$ & $15.6(6.9-31.6)$ & $\begin{array}{l}12.1(2.7-61.2) \\
{ }^{*} P=0.53\end{array}$ \\
\hline
\end{tabular}

${ }^{\star} P$ values indicate CF-NGT compared with CF-DM, ${ }^{* \star} P$ values indicate CF patients compared with controls.

Table 2 BMI, basal concentrations of IGF-I and IGFBP-3 and GH peak concentration in response to arginine stimulation in diabetic CF patients (CF-DM), patients with normal glucose tolerance (CF-NGT) and healthy controls. Values are median (range).

\begin{tabular}{|c|c|c|c|c|}
\hline & $\begin{array}{l}\text { Controls } \\
(n=20)\end{array}$ & $\begin{array}{l}\text { CF-NGT } \\
(n=10)\end{array}$ & $\begin{array}{l}\text { CF-DM } \\
(n=10)\end{array}$ & $\begin{array}{l}\text { CF-NGT and CF-DM } \\
\qquad(n=20)\end{array}$ \\
\hline BMI & $23.17(19.5-26.2)$ & $\begin{array}{l}19.64(15.4-25.1) \\
{ }^{*} P=0.71\end{array}$ & $19.26(16.7-23.2)$ & $\begin{array}{l}19.50(15.4-25.1) \\
* * P=0.0001\end{array}$ \\
\hline IGF-I (ng/ml) & $228(134-393)$ & $\begin{array}{l}154(82-264) \\
{ }^{*} P=1.0\end{array}$ & $163(59-298)$ & $\begin{array}{l}157(59-298) \\
{ }^{* *} P=0.003\end{array}$ \\
\hline IGFBP-3 (ng/ml) & 3754 (2731-4779) & $\begin{array}{l}2896(1626-4349) \\
{ }^{*} P=0.88\end{array}$ & $2860(1332-3725)$ & $\begin{array}{l}2860(1332-4349) \\
{ }^{* *} P=0.0008\end{array}$ \\
\hline GH peak values (mU/l) & $16.1(0.4-56.1)$ & $\begin{array}{l}29.4(2.9-78.9) \\
{ }^{*} P=0.55\end{array}$ & $26.4(0.9-59.7)$ & $\begin{array}{l}28.5(0.9-78.9) \\
{ }^{* \star} P=0.09\end{array}$ \\
\hline
\end{tabular}

${ }^{*} P$ values indicate CF-NGT compared with CF-DM. ${ }^{* \star} P$ values (Mann-Whitney) indicate CF patients compared with controls.

$\mathrm{GH}$ release in response to arginine stimulation was evaluated by peak GH concentration (Table 2). There was no significant difference between patients and controls. The patients seemed to obtain higher peak concentrations than controls; however, the range was wide and the comparison showed no statistically significant difference (Table 2).

There was a significant negative correlation between peak GH concentration during arginine stimulation and BMI $(r=-0.61, P<0.0001)$.

Basal levels of IGF-I and IGFBP-3 were significantly reduced in CF patients compared with controls (Table 2). IGF-I but not IGFBP-3 showed a significant positive correlation to BMI $(r=0.42, P<0.01)$.

Peak GH concentrations during arginine stimulation correlated significantly to mean spontaneous GH concentration $(r=0.43, P<0.01)$, maximal spontaneous GH concentration $(r=0.43, P<0.01)$ and AUC to baseline $(r=0.35, P<0.05)$.
Linear regression analysis for both patients and controls showed that the stimulated $\mathrm{GH}$ release did not correlate to IGF-I or IGFBP-3.

The spontaneous GH secretion correlated to IGF-I and IGFBP-3 since GH peak area and peak amplitude correlated to IGF-I $(r=0.49, P<0.05$ and $r=0.59$, $P<0.01$ respectively), and mean $\mathrm{GH}$ secretion, AUC to baseline and peak amplitude correlated to IGFBP-3 $(r=0.55, \quad P<0.05 ; \quad r=0.45, \quad P<0.05 ; \quad r=0.49$, $P<0.05$ respectively).

\section{Discussion}

We found normal spontaneous and stimulated $\mathrm{GH}$ levels in patients with CF. Previous studies on GH release in patients with $\mathrm{CF}$ have been conflicting as normal, increased and decreased $\mathrm{GH}$ concentrations have been demonstrated (Table 3). This inconsistency may be explained by several circumstances such as 
CF

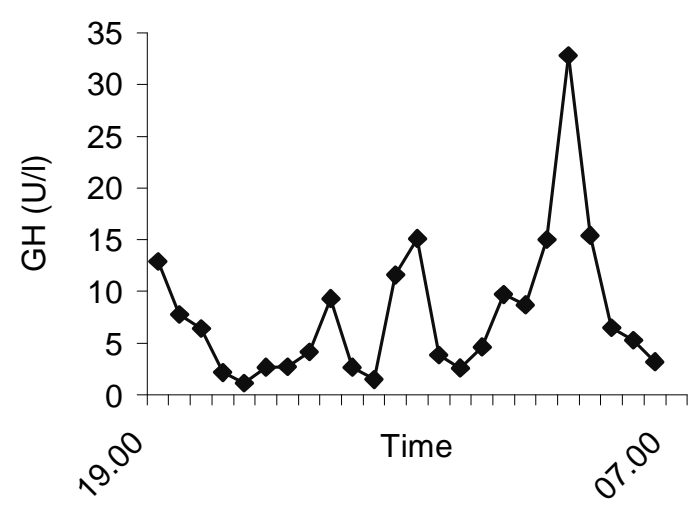

CF

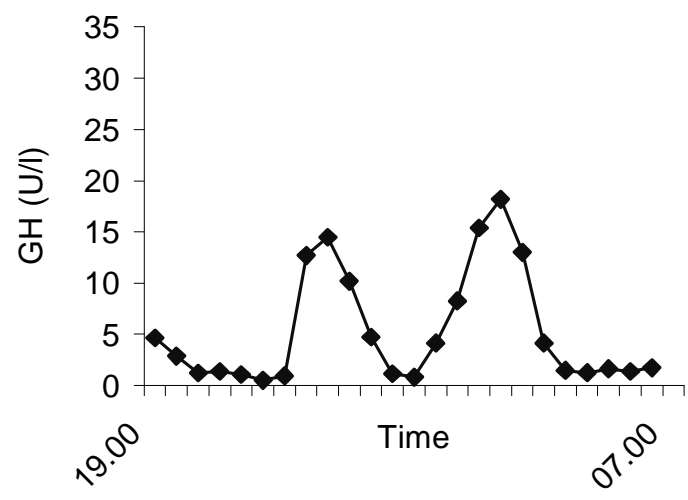

CF

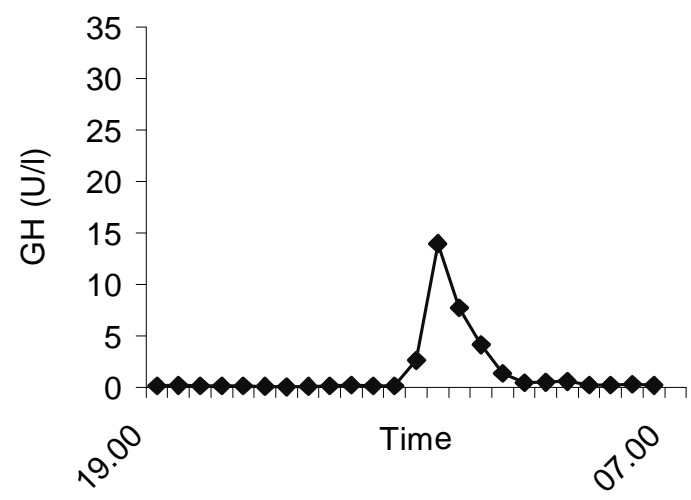

\section{Control}

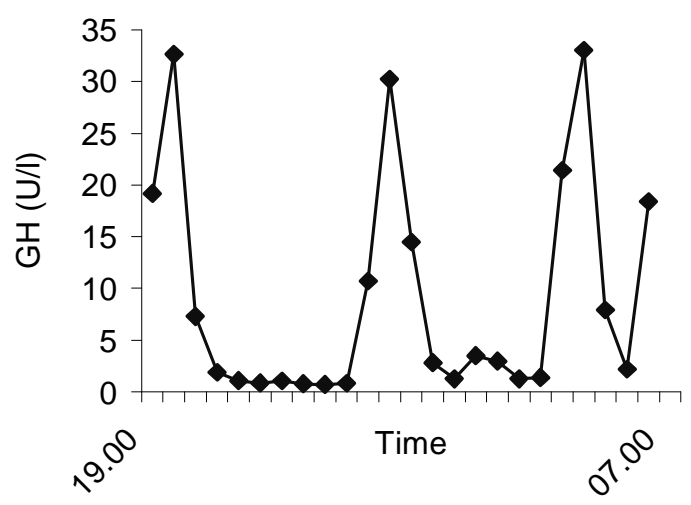

Control

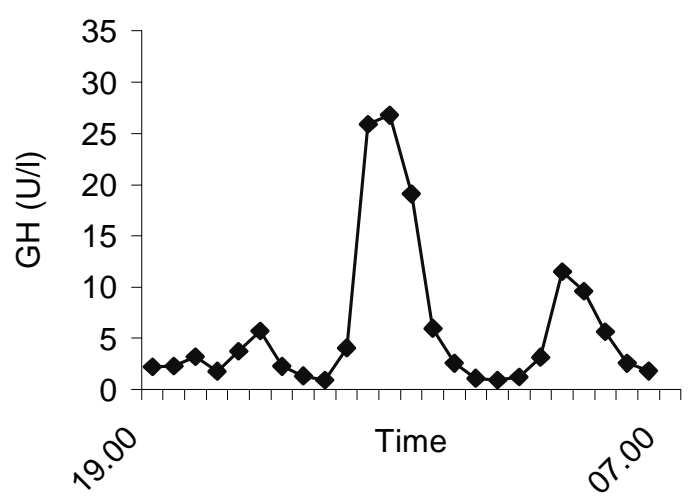

Control

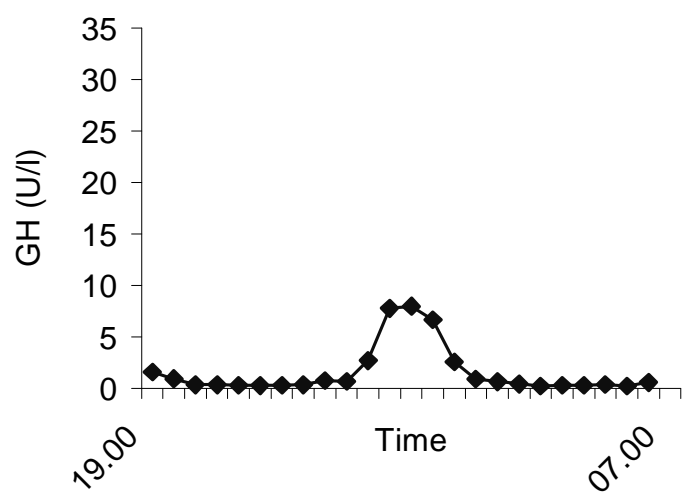

Figure $1 \mathrm{GH}$ profiles in three individual CF patients (left panels) and three healthy controls (right panels). Top panels, high GH release; middle panels, medium $\mathrm{GH}$ release; bottom panels, low $\mathrm{GH}$ release. 


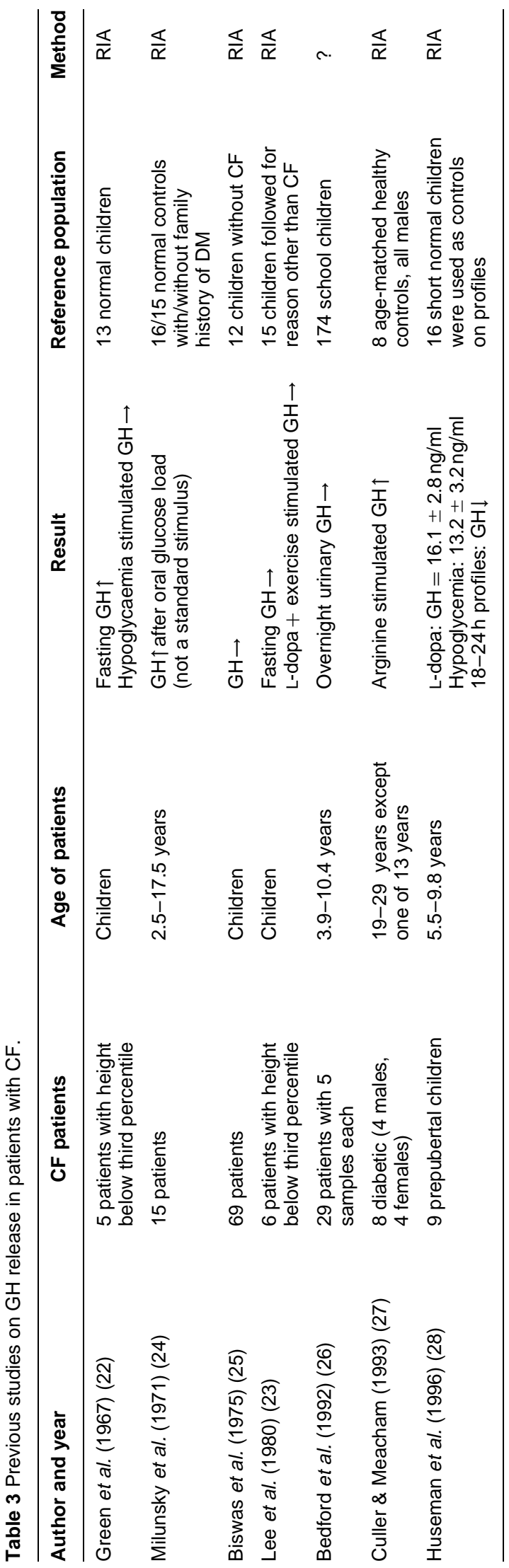

differences in the study and reference populations and difficulties in the assessment of GH status.

Two reports dealt with severely growth-retarded children $(22,23)$. One study (24) did not use a standard stimulus for investigating GH release and one study (25) did not specify the circumstances under which GH was measured. Measurements of urinary GH (26) may be interfered with by the various medications taken by $\mathrm{CF}$ patients. Aminoglycosides may cause reversible or irreversible damage to the kidney and influence the urinary output of $\mathrm{GH}$.

Three studies $(23,27,28)$ used standard conditions and methods that are in accordance with the present methods used for GH assessment. The first (23) showed normal GH concentrations in growth-retarded children with $\mathrm{CF}$, the second (27) showed increased GH concentrations in adult diabetic patients and the third (28) showed decreased concentrations of $\mathrm{GH}$ in prepubertal children with CF. Thus, a disturbance of the GH/IGF-I axis may be possible, but data are at present limited.

We confirmed the work of Lee et al. (23) by the finding of normal stimulated concentrations of $\mathrm{GH}$, although the study of Lee et al. concerned growth-retarded children and the present study concerned adult patients. Furthermore, we found normal spontaneous $\mathrm{GH}$ release during the night. In contrast Culler \& Meacham (27) found increased arginine-stimulated $\mathrm{GH}$ release in diabetic $\mathrm{CF}$ patients compared with healthy controls. However, the control group in Culler's study consisted of eight males whereas the group of CF patients consisted of four males and four females. As females have higher GH release than males $(29,30)$ this difference in gender may have biased the result.

In the study of Huseman et al. (28) of 18-24h GH profiles, decreased GH secretion was found. The control group in this study was short normal children and it was not specified how these short children were classified as normal.

Meacham et al. (31) found that the basal levels of somatostatin were normal in diabetic CF patients, whereas peak concentrations of somatostatin after arginine stimulation were significantly increased compared with normal controls. This corresponds to the finding of a relative preservation of somatostatin secreting delta cells in pancreatic tissue from both diabetic CF patients and CF patients with NGT $(32,33)$. The study of stimulated GH release by Culler \& Meacham (27) was done in continuation of this, and it was concluded that the increased somatostatin concentrations were not of sufficient magnitude to suppress pituitary $\mathrm{GH}$ release since $\mathrm{GH}$ release was increased rather than decreased in diabetic CF patients. As already discussed, the difference in gender in the controls may have biased the result and it may be possible that increased somatostatin concentrations prevented the expected GH increase in the present study.

We did not find any significant differences in the GH/IGF-I/IGFBP-3 axis in diabetic CF patients compared 
with CF patients with NGT. This is in contrast to adolescents with insulin-dependent diabetes mellitus (IDDM) and in poorly controlled patients with IDDM where an abnormally high GH secretion and relative IGF-I deficiency have been observed $(14,15)$. It is, however, in accordance with our previous finding of equal concentrations of IGF-I and IGFBP-3 in diabetic CF patients compared with patients with NGT during the period of 5 years that preceded the diabetic diagnosis (34).

In accordance with our previous finding (7) IGF-I concentrations were reduced in $\mathrm{CF}$ patients compared with controls. Because of the reduced IGF-I concentrations we would have expected increased GH secretion due to the lack of negative feedback from IGF-I on the pituitary gland. The combination of normal GH secretion and reduced IGF-I and IGFBP-3 concentrations may point to a relative $\mathrm{GH}$ resistance or a disturbance in the pituitary axis. However, it may also be due to the difficulties associated with the assessment of GH status.

$\mathrm{GH}$ is difficult to assess and the stimulated $\mathrm{GH}$ release may vary considerably in healthy controls $(35,36)$. However, this should be partly compensated for by the design of this study with age- and sex-matched healthy controls. The evaluation of 12 or $24 \mathrm{~h} \mathrm{GH}$ profiles has been suggested to be superior to stimulation tests $(37,38)$, but this is still controversial (39).

A relative $\mathrm{GH}$ resistance in $\mathrm{CF}$ may be due to increased catabolism, malnutrition or, in the older patients, chronic infection. There have been several former studies on GH and IGF-I secretion in various conditions of malnutrition and increased catabolism such as anorexia nervosa, kwashiorkor, marasmus and healthy starving subjects. An increased basal concentration of $\mathrm{GH}$ during malnutrition is consistently found in these studies (40-43). In both healthy starving subjects (42) and in patients with anorexia nervosa (41) the $24 \mathrm{~h}$ profiles of $\mathrm{GH}$ have revealed increased GH secretion. On the other hand, Soliman et al. (43) found a blunted response to arginine in severely malnourished children. However, fasting GH levels were increased and the blunted response may be caused by the circumstance that GH was already maximally stimulated by the condition of starvation (43). Hochberg et al. (44) found decreased concentrations of GH-binding protein, significantly lower binding capacity of $\mathrm{GH}$ and increased IGF-I binding on red blood cells in anorexia nervosa and proposed that anorexia nervosa presents a condition of $\mathrm{GH}$ resistance and IGF-I hypersensitivity.

Patients with CF cannot be compared with any of these conditions but there are some similarities. CF patients may present a catabolic condition by the combination of chronic pulmonary infection and poorly controlled malabsorption. Many older patients have reduced BMI although not to the same extent as patients with anorexia nervosa. The findings of normal or increased GH secretion in the various studies may be related to changes in BMI and in our study GH secretion in response to arginine stimulation and mean $\mathrm{GH}$ secretion from the profiles showed a significant negative correlation to BMI.

\section{References}

1 Kollberg H. Diagnosis and main clinical features of cystic fibrosis with special attention to screening procedures. Acta Paediatrica Scandinavica Supplementum 1982301 15-25.

2 Frederiksen B, Lanng S, Koch C \& Høiby N. Improved survival in the Danish center-treated cystic fibrosis patients: results of aggressive treatment. Pediatric Pulmonology 1996 21 153-158.

3 Lanng S, Thorsteinsson B, Nerup J \& Koch C. Influence of the development of diabetes mellitus on clinical status in patients with cystic fibrosis. European Journal of Pediatrics 1992151 684-687.

4 Landon C \& Rosenfeld RG. Short stature and pubertal delay in cystic fibrosis. Pediatrician 198714 253-260.

5 Johannesson M, Gottlieb C \& Hjelte L. Delayed puberty in girls with cystic fibrosis despite good clinical status. Pediatrics 199799 29-34.

6 Mahaney MC \& McCoy KS. Developmental delays and pulmonary disease severity in cystic fibrosis. Human Biology 198658 445-460.

7 Laursen EM, Juul A, Lanng S, Høiby N, Koch C, Müller J \& Skakkebæk NE. Diminished concentrations of insulin-like growth factor I in cystic fibrosis. Archives of Disease in Childhood 199572 494-497.

8 Taylor AM, Bush A, Thomson A, Oades PJ, Marchant JL, Bruce Morgan C, Holly J, Ahmed L \& Dunger DB. Relation between insulin-like growth factor-I, body mass index, and clinical status in cystic fibrosis. Archives of Disease in Childhood 199776 304-309.

9 Hindmarsh PC \& Brook CGD. Normal growth and its endocrine control. In Clinical Paediatric Endocrinology, edn 3, ch 6, pp 85106. Ed. CGD Brook. Oxford: Blackwell Science Ltd, 1995.

10 Cotterill AM \& Savage MO. Growth-hormone-resistant states. In Clinical Paediatric Endocrinology, edn 3, pp 187-194. Ed. CGD Brook. Oxford: Blackwell Science Ltd, 1995.

11 Rosenbloom AL, Rosenfeld RG \& Guevara-Aguirre J. Definition and classification of growth hormone insensitivity. Pediatric Clinics of North America 199744 423-442.

12 Clemmons DR, Underwood LE, Dickerson RN, Brown RO, Hak LJ, Macphee RD \& Heizer WD. Use of plasma somatomedin-c/ insulin-like growth factor-I measurements to monitor the response to nutritional depletion in malnourished patients. American Journal of Clinical Nutrition 198541 191-198.

13 Ross RJM, Miell JP, Freeman E, Jones J, Matthews DR, Preece MA \& Buchanan C. Critically ill patients have high basal growth hormone levels with attenuated oscillatory activity associated with low levels of insulin-like growth factor-I. Clinical Endocrinology 199135 47-54.

14 Dunger DB, Cheetham TD, Holly JMP \& Matthews DR. Does recombinant insulin-like growth factor I have a role in the treatment of insulin-dependent diabetes mellitus during adolescence? Acta Paediatrica Scandinavica 1993388 (Suppl) 49-52.

15 Langford KS \& Miell JP. The insulin-like growth factor-I/binding protein axis: physiology, pathophysiology and therapeutic manipulation. European Journal of Clinical Investigation 199323 503-516.

16 Heinze E \& Holl RW. Tests for beta-cell function in childhood and adolescence. In Diagnostics of Endocrine Function in Children and Adolescents, edn 2, pp 299-313. Ed. MB Ranke. Heidelberg, Leipzig: Johann Ambrosius Barth Verlag, 1996.

17 Kowarski A, Thompson RG, Migeon CJ \& Blizzard RM. Determinations of integrated plasma concentrations and true secretion rates of human growth hormone. Journal of Clinical Endocrinology and Metabolism 197132 356-360. 
18 Meriam GR \& Watcher KW. Algorithms for the study of episodic hormone secretion. American Journal of Physiology 1982243 E310-E318.

19 Rasmussen MH, Hvidberg A, Juul A, Main K, Gotfredsen A, Skakkebæk NE \& Hilsted J. Massive weight loss restores 24-h growth hormone release profiles and serum insulin-like growth factor-I levels in obese subjects. Journal of Clinical Endocrinology and Metabolism 199580 1407-1415.

20 Juul A, Bang P, Hertel NT, Main K, Dalgaard P, Jørgensen K, Müller J. Hall K \& Skakkebæk NE. Serum insulin-like growth factor-I in 1030 healthy children, adolescents, and adults: relation to age, sex, stage of puberty, testicular size, and body mass index. Journal of Clinical Endocrinology and Metabolism 1994 $78744-752$.

21 Blum W, Ranke M, Kietzmann K, Gauggel E, Zeisel H \& Bierich J. A specific radioimmunoassay for the growth hormone (GH)-dependent somatomedin-binding protein: its use for diagnosis of GH-deficiency. Journal of Clinical Endocrinology and Metabolism 199070 1292-1298.

22 Green OC, Fefferman R \& Nair S. Plasma growth hormone levels in children with cystic fibrosis and short stature. Unresponsiveness to hypoglycemia. Journal of Clinical Endocrinology 196727 1059-1061.

23 Lee JA, Dickinson LS, Kilgore BS, Warren RH \& Elders MJ. Somatomedin activity in cystic fibrosis and reserpinized rats: possible explanation for growth retardation. Annals of Clinical and Laboratory Science 198010 227-233.

24 Milunsky A, Bray GA, Londono J \& Loridan L. Insulin, glucose growth hormone and free fatty acids. Determinations in patients with cystic fibrosis. American Journal of Diseases in Childhood 1971 121 15-19.

25 Biswas S, Norman AP, Baffoe G \& Graves L. Prolactin, growth hormone and alpha-fetoprotein in children with cystic fibrosis. Clinica Chimica Acta 197669 541-542.

26 Bedford CD, Skinner A, Soo A, Heaf DP, Price DA \& Addison GM. Overnight urinary growth hormone excretion in patients with cystic fibrosis. [Abstract] MP53. XIth International Cystic Fibrosis Congress. 24-27 August 1992. Dublin, Ireland.

27 Culler FL \& Meacham LR. Effect of hypersomatostatinemia on growth hormone secretion in cystic fibrosis patients with diabetes. Clinical Neuroendocrinology 199358 473-477.

28 Huseman CA, Colombo JL, Brooks MA, Smay JR, Greger NG Sammut PH \& Bier DM. Anabolic effect of biosynthetic growth hormone in cystic fibrosis patients. Pediatric Pulmonology 199622 90-95.

29 Ho KY, Evans WS, Blizzard RM, Veldhuis JD, Merriam GR, Samojlik E, Furlanetto R, Rogol AD, Kaiser DL \& Thorner MO. Effects of sex and age on the 24-h profile of growth hormone secretion in man: importance of endogenous estradiol concentrations. Journal of Clinical Endocrinology and Metabolism 198764 $51-58$.

30 Van den Berg G, Veldhuis JD, Frölich M \& Roelfsema F. An amplitude-specific divergence in the pulsatile mode of growth hormone $(\mathrm{GH})$ secretion underlies the gender difference in mean GH concentrations in men and premenopausal women. Journal of Clinical Endocrinology and Metabolism $1996 \quad 81$ 2460-2467.

31 Meacham LR, Caplan DB, McKean LP, Buchanan CN, Parks JS \& Culler FL. Preservation of somatostatin secretion in cystic fibrosis patients with diabetes. Archives of Disease in Childhood 199368 123-125.
32 Abdul Karim FW, Dahms BB, Velasco ME \& Rodman HM. Islets of Langerhans in adolescents and adults with cystic fibrosis. A quantitative study. Archives of Pathology in Laboratory Medicine $1986110602-606$.

33 Soejima K \& Landing BH. Pancreatic islets in older patients with cystic fibrosis with and without diabetes mellitus. Pediatric Pathology $1986625-46$.

34 Laursen EM. Growth, growth hormone and growth factors in patients with cystic fibrosis. PhD Thesis, University of Copenhagen, Denmark, 5 November 1998.

35 Vahl N, Jorgensen JO, Jurik AG \& Christiansen JS. Abdominal adiposity and physical fitness are major determinants of the age associated decline in stimulated GH secretion in healthy adults. Journal of Clinical Endocrinology and Metabolism 199681 2209-2215.

36 Ghigo E, Bellone J, Aimeretti G, Bellone S, Loche S, Cappa M, Bartolotta E, Dammacco F \& Camanni F. Reliability of provocative tests to assess growth hormone secretory status. Study in 472 normally growing children. Journal of Clinical Endocrinology and Metabolism 199681 3323-3327.

37 Zadik Z, Chalew SA, Gilula Z \& Kowarski AA. Reproducibility of growth hormone testing procedures: a comparison between 24-h integrated concentration and pharmacological stimulation. Journal of Clinical Endocrinology and Metabolism 199071 1127-1130.

38 Bercu BB, Shulman D, Root AW \& Spiliotis BE. Growth hormone $(\mathrm{GH})$ provocative testing frequently does not reflect endogenous GH secretion. Journal of Clinical Endocrinology and Metabolism $198663709-716$.

39 Rose SR, Ross JL, Uriarte M, Barnes KM, Cassorla FG \& Cutler GB Jr. The advantage of measuring stimulated as compared with spontaneous growth hormone levels in the diagnosis of growth hormone deficiency. New England Journal of Medicine 1988319 201-207.

40 Cabranes JA, Almoguera I, Santos JL, Hidalgo I, Borque M \& Del Olmo J. Somatomedin-C and growth hormone levels in anorexia nervosa in relation to the puberal or post puberal stages. Progress in Neuro-Psychopharmacology and Biological Psychiatry $198812865-871$.

41 Ferrari E, Fraschini F \& Brambilla F. Hormonal circadian rhythms in eating disorders. Biological Psychiatry 199027 1007-1020.

42 Fichter MM, Pirke K \& Holsboer F. Weight loss causes neuroendocrine disturbances: experimental study in healthy starving subjects. Psychiatry Research 199617 61-72.

43 Soliman AT, Hassan AI, Aref MK, Hintz RL, Rosenfeld RG \& Rogol AD. Serum insulin-like growth factors I and II concentrations and growth hormone and insulin responses to arginine infusion in children with protein-energy malnutrition before and after nutritional rehabilitation. Pediatric Research 198620 $1122-1130$

44 Hochberg Z, Hertz P, Colin V, Ish-Shalom S, Yeshurun D, Youdim MBH \& Amit T. The distal axis of growth hormone $(\mathrm{GH})$ in nutritional disorders: GH-binding protein, insulin-like growth factor-I (IGF-I), and IGF-I receptors in obesity and anorexia nervosa. Metabolism 199241 106-112.

Received 29 July 1998

Accepted 4 January 1999 